\title{
Sociodemographic Impact and Acquaintance on Antibiotic Resistance Among Outpatients in Specialist Hospital, Malaysia
}

\author{
Hanish Singh J. C. ${ }^{a, b}$, Mohamed M. M. ${ }^{a}$, Thayashini K. ${ }^{b}$ Long C. M. ${ }^{\text {, }}$, Shafeeq M.F \\ ${ }^{a}$ Department of Pharmacology and Pharmaceutical Chemistry, Faculty of Pharmacy, Universiti Teknologi MARA, 42300 Puncak Alam, Selangor, \\ Malaysia \\ ${ }^{b}$ School of Pharmacy, KPJ Healthcare University College, Kota Seriemas, Nilai, Negeri Sembilan \\ 'PAPRSB Institute of Health Sciences, Universiti Brunei Darussalam, Jalan Tungku Link, BE 1410, Brunei Darussalam \\ ${ }^{d}$ Pharmacy Department, KPJ Seremban Specialist Hospital, Negeri Sembilan
}

\author{
Keywords \\ Antibiotics, knowledge, attitude, \\ awareness, antimicrobial resistance, multi- \\ drug resistance. \\ Corresponding Author \\ Dr. Hanish Singh Jayasingh Chellammal \\ Department of Pharmacology and \\ Pharmaceutical Chemistry, \\ Faculty of Pharmacy, Universiti Teknologi \\ MARA, 42300 Puncak Alam, Selangor, \\ Malaysia \\ Tel No: +601115096775 \\ E-mail: hanishsinghjc@uitm.edu.my \\ Received: 29 May 2020; Accepted: 20 April \\ 2021 \\ Doi: https://doi.org/10.31436/imjm.v20i3
}

\begin{abstract}
INTRODUCTION: Awareness on antibiotics resistance among outpatients in hospital settings is reasonably explored and this study aimed to investigate the sociodemographic impact and the level of acquaintance towards antibiotics practice and resistance. MATERIALS AND METHODS: This cross-sectional study was conducted on 270 patients from the outpatient department of KPJ Seremban Specialist Hospital (KPJSSH), Malaysia. A pre-validated questionnaire was used to collect the data on the demographics of the patients, their knowledge, attitude, and usage of antibiotics. The study was approved by the KPJUC ethics committee (KPJUC/RMC/BPH/EC/2017/104). RESULTS: The mean age of the respondents was $36 \pm 11.07$ years and $50.37 \%$ of them have moderate knowledge on antibiotics. The knowledge and attitude on antibiotics usage exhibited a significant difference $(p=0.001)$ amongst these patients in association with literacy. The results showed that the literate respondents have significant knowledge on the identification of antibiotics $(p=0.021)$, their roles, and adverse effects $(p=0.004)$. The attitude of the respondents towards following the prescription was significantly associated with their literacy $(\mathrm{p}=0.004)$. CONCLUSION: This study reveals that respondents have the least knowledge on antibiotic course compliance and termination of therapy, which could lead to antimicrobial resistance. In conclusion, inculcating the knowledge of antimicrobial resistance, adverse effects, and course compliance among the patients may help overcome the national and global issues on multi-drug-resistant diseases.
\end{abstract}

\section{INTRODUCTION}

Antibiotics have been lifesaving drugs and are distinctive medications for mankind to treat various infections. Despite the clinical importance of antibiotics, antimicrobial resistance (AMR) is a critical concern when they are used irrationally. AMR contributes to extensive health issues and escalates mortality and morbidity as reported by the World Health Organization (WHO) Global Surveillance report 2014. Antibiotics resistance has reached a critical state in some regions of the world. The current lack of new antibiotics development on the horizon adds pressure to protect the efficacy of present drugs. ${ }^{1}$ In 2019, $\mathrm{WHO}^{2}$ called for immediate action to avert the AMR crisis and predicted that death due to drug-resistant ailments may increase up to 10 million by 2050 with the economic crisis. It is predicted that by 2030, AMR may lead to poverty among 24 million people in the world. Currently, around 700,000 deaths are reported every year due to AMR diseases, including 230,000 people with multidrug-resistant tuberculosis. ${ }^{2}$ Easy access to the drugs, ignoring health policies on antibiotics regulation, over-the-counter purchase, selfmedication practices, and patient's inadequate knowledge on antibiotic medications leads to clinical issues. ${ }^{3}$ Acquiring non-prescription antibiotics is also a 
key factor for misuse. ${ }^{4}$ Therefore, antibiotics use requires achievable intervention, patient counselling, and also relies on the patient's knowledge and perception. Many strategies can instill accurate practice of antibiotics such as through formulary replacement or restriction, healthcare counselling, feedback events, and therapeutic drug monitoring from infectious disease specialists. ${ }^{5}$ An increased in antibiotics resistance was observed for most antibiotic drugs (National antibiotic surveillance report, Malaysia). ${ }^{6}$ The perplexity in the role of antibiotics for treating specific infections among the public leads to a major risk for antibiotics resistance. Non-compliance in medication course and attitude of the patient were also the factors for AMR. ${ }^{7}$ Studies on AMR knowledge among the outpatients visiting the hospital is lacking as compared to studies on public community and healthcare students ${ }^{8-10}$. The awareness of AMR is lacking among the patients visiting hospitals and required to take measures to address the issues pertaining to AMR. ${ }^{11}$ Therefore this study aimed to evaluate the sociodemographic impact and knowledge on AMR and antibiotics utilisation among outpatients in a hospital setting.

\section{METHODOLOGY}

A cross-sectional study was performed on demographics and correlated to the knowledge towards antibiotics usage among outpatients in the pharmacy department at KPJ Seremban Specialist Hospital (KPJSSH). The study was conducted from5th March 2018 to 28th September 2018 using a pre-validated questionnaire as an instrument to collect the information. ${ }^{12}$ The questionnaire is structured in the English and Bahasa Melayu version consisting of four parts. The first part comprises demographic factors consisting of five questions. The second part identifies the frequency of antibiotic consumption within one month, the source of antibiotic, and the reason for consumption. The third part consisted of 14 statements which are further divided into five aspects. This involved antibiotic identification, role of antibiotic, antibiotic and adverse effects, allergic reaction, antibiotic resistance, and compliance of antibiotics. The fourth part consisted of eight statements on attitude towards antibiotic usage. The survey consent letter included the aim of the research and the confidentiality of patient data. The sample size was calculated by Daniels equation: $n=\left[\begin{array}{l}Z 2 \\ \text { x }\end{array}\right.$ addition of $10 \%$, totalling 270 samples. ${ }^{13}$ Patients below 18 years of age, visually challenged, and hearing impaired were excluded from this study. The study was approved and adhered to the regulations of the ethics committee, KPJ Healthcare University College (KPJUC/RMC/BPH/EC/2017/104).

\section{STATISTICAL ANALYSIS}

Data were analysed using the IBM SPSS application, version 26. The demographic characteristics, recent use of antibiotics, knowledge, and attitude towards antibiotics usage were summarised using descriptive statistics. The Chi-Square or Fishers Exact tests were used to test the associations between knowledge and attitude with sociodemographic factors. The Spearman rank correlation was used to differentiate the relationship between knowledge and attitude towards antibiotic usage. The factor was considered to be statistically significant if the $p$-value is $<0.05$.

\section{RESULTS}

The questionnaire is responded to by 285 respondents. Considering inclusion and exclusion criteria $15(\mathrm{~N}=15)$ responses were excluded and a total of 270 were analysed. The demographic data and pattern of antibiotic consumption are displayed in Tables 1 and 2 . The mean age of the respondents was $36.4 \pm 11.07$ years, the majority of whom aged between 20-59 years $40 \%$ of the respondents were aged between 30-39 and $157(58.1 \%)$ of them were females and $113(41.9 \%)$ were males. Most of the visitors in KPJSSH were Malays, 188 (69.6\%) followed by Indians, 41 (15.2\%), and Chinese $38(14.1 \%)$. In terms of education level, $185(68.5 \%)$ respondents had the highest qualification of college or university, while 71 (26.3\%) have secondary school level. Only 7 respondents were recorded in primary school and -no education category. The sociodemographic characteristics of respondents are shown in Table 1. 
Table 1: Demographic characteristics

\begin{tabular}{|c|c|c|}
\hline \multicolumn{3}{|c|}{ Demographics characteristics } \\
\hline \multicolumn{2}{|l|}{ Characteristics } & $\begin{array}{l}\text { Number (n) and } \\
\text { Percentage }(\%)\end{array}$ \\
\hline \multirow[t]{4}{*}{ Age (Years) } & $<20$ & $5(1.9)$ \\
\hline & $\begin{array}{l}20-29 \\
30-39 \\
40-49\end{array}$ & $\begin{array}{l}74(27.4) \\
104(38.5) \\
49(18.1)\end{array}$ \\
\hline & $50-59$ & $29(10.7)$ \\
\hline & $>60$ & $9(3.3)$ \\
\hline \multirow[t]{2}{*}{ Gender } & Male & $113(41.9)$ \\
\hline & Female & $157(58.1)$ \\
\hline \multirow[t]{4}{*}{ Race } & Malay & $188(69.6)$ \\
\hline & Chinese & $38(14.1)$ \\
\hline & Indian & $41(15.2)$ \\
\hline & Others & $3(1.1)$ \\
\hline \multirow[t]{4}{*}{ Literacy } & Primary school & $7(2.6)$ \\
\hline & Secondary school & $71(26.3)$ \\
\hline & University & $185(68.5)$ \\
\hline & None & $7(2.6)$ \\
\hline \multirow{5}{*}{$\begin{array}{l}\text { Monthly } \\
\text { income } \\
(\mathrm{RM})\end{array}$} & $<1000$ & $8(3.0)$ \\
\hline & $1000-2000$ & $47(17.4)$ \\
\hline & $2001-4000$ & 85 (31.5) \\
\hline & $>4000$ & $88(32.6)$ \\
\hline & None & $42(15.6)$ \\
\hline
\end{tabular}

As shown in Table 2, 100 (37.4\%) respondents had been prescribed with antibiotics while 170 (62.6\%) stated no antibiotic medication. Of those who were given antibiotics, the majority received treatment from consultants/specialists (100 respondents). The most frequent reason was fever, followed by pain or inflammation. Table 3 shows the analysis of the level of knowledge of the respondents on the antibiotic. These results exposed that the majority have a moderate level of knowledge (Table 3). The level of knowledge indicated $50.3 \%$ of patients has a moderate knowledge level whereas $29.60 \%$ reveals poor knowledge and $20.37 \%$ exhibits good knowledge. The sociodemographic correlation indicated that patients with higher literacy (College/ University education) have a significant difference $(\phi<0.001)$ in knowledge. The main components evaluated were the role of antibiotics, identification of antibiotics, hazards of antibiotics, and their treatment courses (Table 4).

Table 4 displays the level of knowledge of the respondents towards the role of antibiotics, hazards of antibiotics, and their treatment courses. 214 (79.3\%) of the respondents know that antibiotics are used to treat
Table 2: Usage of antibiotics

\begin{tabular}{ll}
\hline $\begin{array}{l}\text { In the past } 1 \text { month, have you taken any } \\
\text { antibiotics? }\end{array}$ & $\begin{array}{l}\text { Frequency -N } \\
\text { (Percentage-\%) }\end{array}$ \\
\hline Yes & $100(37.4)$ \\
No & $170(62.6)$ \\
Total & $\mathbf{2 7 0}(\mathbf{1 0 0})$ \\
\hline $\begin{array}{l}\text { Source of antibiotics taken is form } \\
\text { Prescribed by hospital/ clinic after a }\end{array}$ & $\begin{array}{l}\text { Frequency-N } \\
\text { (Percentage- } \%)\end{array}$ \\
consultation & $90(90)$ \\
Purchased from a private clinic with & $9(9)$ \\
doctor consultation & $1(1)$ \\
Purchased from retail pharmacy & $100(\mathbf{1 0 0})$ \\
Total & $\begin{array}{l}\text { Frequency-N } \\
(\text { Percentage- } \%)\end{array}$ \\
\hline Reason for taking antibiotics & $10(10)$ \\
Respiratory illness & $14(14)$ \\
Skin problem/wound & $6(6)$ \\
Urinary tract infection & $44(44)$ \\
Fever & $17(17)$ \\
Pain/Inflammation & $9(9)$ \\
Others & $\mathbf{1 0 0 ( 1 0 0 )}$ \\
Total &
\end{tabular}

bacterial infection. Gender and educational background indicated a significant difference $(p=0.032,0.021)$ in response to the knowledge in antibiotics. Regarding the course of antibiotics, $72(26.7 \%)$ respondents stated that antibiotics cannot be stopped upon the improvement of symptoms. 171 (63.3\%) respondents responded incorrectly that antibiotics can be stopped upon improving the symptoms, and only $27(10.0 \%)$ were unsure. This indicates that even with the high education and income group, no positive influence on course completion of antibiotic medication can be made. Statements of attitude were analysed and the results are depicted in Table 5 .

Each of the statements indicates the attitude of patients towards antibiotics. Comparing the responses with educational background and monthly income, a significant difference of $(p=0.004,0.011)$ which indicates positive attitude of educated respondents can be seen. Nearly half of the respondednts 150 (55.6\%) disagree with the termination of antibiotics upon feeling better from the ailments, while 96 (35.6\%) agree with the termination and $24(8.9 \%)$ were unsure. 238 $(88.1 \%)$ respondents agreed that they are taking antibiotics as per the label while, 17 (6.3\%) disagreed. There is a significant difference $(p=0.002)$ in the level on knowledge on comparing educational background. The number of respondents who cross-verifies the 
Table 3: Knowledge of antibiotics among the respondents

\begin{tabular}{|c|c|c|c|c|c|}
\hline \multirow{2}{*}{ Characteristics } & & \multicolumn{3}{|c|}{ Level of knowledge } & \multirow[t]{2}{*}{$p$-value } \\
\hline & & $\begin{array}{c}\text { Poor } \\
\mathrm{N}(\%)\end{array}$ & $\begin{array}{c}\text { Moderate } \\
\mathrm{N}(\%)\end{array}$ & $\begin{array}{l}\text { Good } \\
\mathrm{N}(\%)\end{array}$ & \\
\hline \multirow{7}{*}{ Age (Years) } & $<20$ & $2(0.74)$ & $3(1.11)$ & $0(0.0)$ & \\
\hline & $20-29$ & $20(7.41)$ & $45(16.67)$ & $9(3.33)$ & \\
\hline & $30-39$ & $28(10.37)$ & $46(17.04)$ & 30 (11.11) & \\
\hline & $40-49$ & $16(5.93)$ & $25(9.26)$ & $8(2.96)$ & \\
\hline & $50-59$ & $10(3.70)$ & $14(5.19)$ & $5(1.85)$ & \\
\hline & $>60$ & $3(1.11)$ & $3(1.11)$ & $3(1.11)$ & \\
\hline & Total respondents (270) & $79(29.26)$ & $136(50.37)$ & 55 (20.37) & \\
\hline \multirow{2}{*}{ Gender } & Male & $31(11.48)$ & $59(21.85)$ & $23(8.52)$ & \\
\hline & Female & $48(17.78)$ & $77(28.52)$ & $32(11.85)$ & \\
\hline \multirow{4}{*}{ Race } & Malay & 57 (21.11) & $95(35.19)$ & $36(13.33)$ & \\
\hline & Chinese & $11(4.07)$ & $17(6.30)$ & $10(3.70)$ & \\
\hline & Indian & $8(2.96)$ & $24(8.89)$ & $9(3.33)$ & \\
\hline & Others & $3(1.11)$ & $0(0.0)$ & $0(0.0)$ & \\
\hline \multirow{4}{*}{ literacy } & Primary school & $3(1.11)$ & $4(1.48)$ & $0(0.0)$ & \multirow{4}{*}{$0.001 *$} \\
\hline & Secondary School & $32(11.85)$ & $35(12.96)$ & $4(1.48)$ & \\
\hline & College/ University & $41(15.19)$ & $94(34.81)$ & $50(18.52)$ & \\
\hline & None & $3(1.1)$ & $3(1.11)$ & $1(, 037)$ & \\
\hline \multirow{5}{*}{ Monthly income } & $<$ RM 1000 & $3(1.11)$ & $3(1.11)$ & $2(0.74)$ & \\
\hline & RM1000-2000 & $15(5.56)$ & $26(9.63)$ & $6(2.22)$ & \\
\hline & RM2001-4000 & $30(11.11)$ & $38(14.07)$ & $17(6.30)$ & \\
\hline & $>$ RM 4000 & $16(5.93)$ & $48(17.78)$ & $24(8.89)$ & \\
\hline & None & $15(5.56)$ & $21(7.78)$ & $6(2.22)$ & \\
\hline
\end{tabular}

expiry date before taking the medicine is high 247 $(91.5 \%)$ and exhibits a significant difference $(p=0.011)$ in attitude with education, while $11(4.1 \%)$ disagreed and $12(4.4 \%)$ were unsure.

\section{DISCUSSION}

The current research findings revealed that literacy has a significant impact on the knowledge and attitude of the patients about antibiotics and our study is comparable with the previous study. ${ }^{14}$ In this survey, Malay ethnic respondents understand the importance of differentiating bacterial and viral infection. Patients with a higher level of knowledge reflect intellectually on every aspect to identify the solution and have the tendency to adapt to new experiences. ${ }^{11}$ It's revealed that even though the knowledge in educated patients is good, a common misconceptions such as antibiotics are also used to treat viral infections still exist. . Earlier reports also state the misconception between antibiotic and antiviral drugs. ${ }^{15}$ Most of the people in the community have the least knowledge on the identification of antibiotics and the difference between antibiotics and antipyretics/ anti-inflammatory drugs, indicating that the knowledge level on antibiotics is inadequate. 16,17 The present study indicates that knowledge on antibiotics resistance is poor among patients visiting hospitals. Previous studies also stated that knowledge on AMR and awareness is lacking in the public and measures has to be imparted to improve the knowledge on these aspects.5,18 In this research, it's revealed that even though literate, the respondents have the least knowledge on antibiotic courses and intended to discontinue the medication immediately after symptoms subside. This essentially signifies the importance of antibiotics counselling and awareness programs conducted for the patients and community. Some of the studies indicate that the community is aware of the AMR ${ }^{19}$, but many claim that awareness 
Table 4: Association of sociodemographic characteristics with the level of knowledge

\begin{tabular}{|c|c|c|c|c|c|c|c|c|}
\hline \multirow[t]{2}{*}{ Statement } & \multirow{2}{*}{$\begin{array}{l}\text { Correct } \\
\text { Answer }\end{array}$} & \multirow{2}{*}{$\begin{array}{l}\text { Incorrect } \\
\text { Answer }\end{array}$} & \multirow{2}{*}{ Unsure } & \multicolumn{5}{|c|}{$p$-value (chi-square / Fisher Exact test) } \\
\hline & & & & Age & Gender & Race & Education & Income \\
\hline \multicolumn{9}{|l|}{ Role of Antibiotic } \\
\hline $\begin{array}{l}\text { Antibiotics are medicine that can kill } \\
\text { bacteria }\end{array}$ & $214(79.3 \%)$ & $27(10.0 \%)$ & $29(10.7 \%)$ & 0.298 & $0.032^{*}$ & 0.164 & $0.021 *$ & 0.730 \\
\hline $\begin{array}{l}\text { Antibiotics can be used to treat viral } \\
\text { infections. }\end{array}$ & $169(62.6 \%)$ & $50(18.5 \%)$ & $51(18.9)$ & 0.451 & 0.219 & $0.022^{*}$ & $0.030^{*}$ & 0.496 \\
\hline $\begin{array}{c}\text { Antibiotics are indicated to relieve } \\
\text { pain or inflammation. }\end{array}$ & $100(37.0 \%)$ & $112(41.5 \%)$ & $58(21.5 \%)$ & 0.548 & 0.114 & 0.228 & 0.244 & 0.501 \\
\hline $\begin{array}{l}\text { Antibiotics are used to stop the } \\
\text { fever. }\end{array}$ & $107(39.6 \%)$ & $105(38.9 \%)$ & $58(21.5 \%)$ & 0.545 & 0.133 & $0.008^{*}$ & 0.972 & 0.331 \\
\hline \multicolumn{9}{|l|}{ Identification of Antibiotic } \\
\hline Penicillin is an antibiotic. & $101(37.4 \%)$ & $39(14.4 \%)$ & $130(48.1 \%)$ & 0.659 & 0.772 & 0.433 & 0.958 & 0.474 \\
\hline $\begin{array}{l}\text { Aspirin is a new generation of } \\
\text { antibiotics. }\end{array}$ & $30(11.1 \%)$ & $104(38.5 \%)$ & $136(50.4 \%)$ & 0.608 & 0.344 & 0.196 & 0.261 & $0.009 *$ \\
\hline $\begin{array}{l}\text { Paracetamol is considered as an } \\
\text { antibiotic }\end{array}$ & $26(9.6 \%)$ & $171(63.3 \%)$ & $73(27.0 \%)$ & $0.001 *$ & 0.636 & $0.040^{*}$ & $0.000^{*}$ & $0.054^{*}$ \\
\hline Diphenhydramine is not an antibiotic & $36(13.3 \%)$ & $40(14.8 \%)$ & $194(71.9 \%)$ & 0.828 & 0.863 & $0.036^{*}$ & 0.334 & 0.431 \\
\hline \multicolumn{9}{|l|}{ Dangers of Antibiotic } \\
\hline $\begin{array}{c}\text { Overuse of antibiotic can cause } \\
\text { antibiotic resistance }\end{array}$ & $155(57.4 \%)$ & $25(9.3 \%$ & $90(33.3 \%)$ & 0.679 & 0.073 & 0.251 & 0.514 & 0.448 \\
\hline $\begin{array}{l}\text { Antibiotics may cause an allergic } \\
\text { reaction. }\end{array}$ & $141(52.2 \%)$ & $44(16.3 \%)$ & $85(31.5 \%)$ & 0.436 & 0.268 & 0.102 & $0.004^{*}$ & 0.463 \\
\hline $\begin{array}{l}\text { All antibiotics do not cause side } \\
\text { effects. }\end{array}$ & $38(14.1 \%)$ & $132(48.9 \%)$ & $100(37.0 \%)$ & 0.857 & 0.517 & 0.089 & 0.075 & 0.081 \\
\hline \multicolumn{9}{|l|}{ Completion of Treatment Course } \\
\hline $\begin{array}{l}\text { You can stop taking a full course of } \\
\text { antibiotic if symptoms } \\
\text { improve }\end{array}$ & $72(26.7 \%)$ & $171(63.3 \%)$ & $27(10.0 \%)$ & 0.221 & 0.806 & 0.052 & $0.018^{*}$ & $0.027^{*}$ \\
\hline $\begin{array}{l}\text { The effectiveness of treatment is } \\
\text { reduced if a full course of } \\
\text { antibiotics is not completed }\end{array}$ & $159(58.9 \%)$ & $56(20.7 \%)$ & $55(20.4 \%)$ & 0.962 & 0.099 & $0.017^{*}$ & 0.378 & 0.302 \\
\hline
\end{tabular}

${ }^{*} p<0,05$ considered as statistically significant by Fisher Exact test. Mean scores of Knowledge statements compared with the sociodemographic factors such as age, gender, race, education, and income.

needs to be imparted. ${ }^{18,20,21}$. It's scientifically known that inappropriate usage of antibiotics triggers AMR. Every year around 47 million irrational antibiotic prescriptions are identified in the USA for the treatment of common respiratory diseases. ${ }^{22}$ In Malaysia, antibiotics are the highly utilised drugs for respiratory infections..$^{23}$ National antibiotic surveillance report on Malaysia states that increased resistance to Streptococcus pneumonia, Klebsiella pneumonia, Salmonella typhi were found. The majority of antibiotics (ampicillin/ sulbactam, gentamicin, ceftazidime, imipenem, meropenem, amikacin, and polymyxin B) tested against Acinetobacter baumanii exhibited higher resistance. The resistance to antibiotics like cefuroxime, ceftazidime, and cefotaxime against E.coli have increased to $26.7 \%$, $18.3 \%$, and $27 \%$ respectively during 2017 , compared to $24.8 \%, 18.3 \%$, and $24.8 \%$ in 2016.6 Several studies in Malaysia assessed the public knowledge, attitude, belief, and practice on antibiotic usage and AMR. It was found that poor level of knowledge and attitude contributed to the irrational use of antibiotics and AMR. ${ }^{8}$ In Malaysia, national-level antibiotic campaigns creating awareness on antibiotics and antibiotics resistance should be conducted frequently. This type of awareness activity is less seen in the private hospital setting in comparison with public hospitals and this needs to change hence more awareness campaigns are required.requires to be imparted. Various studies state that majority of respondents have a poor attitude towards correct usage of antibiotics ${ }^{24,25}$. Our study however revealed that the attitude towards antibiotics is positive in some aspects (Table 5) and it was also noticed that the respondents do follow the instructions on the label and check for the expiry date. Furthermore,atients with low income have a poor attitude with the termination, usage of left-over medication and donation of balance drug to the relatives and friends.20,21 The attitude of sharing antibiotics among family members was observed among respondents from the low-income group to reduce the 
Table 5: Association of sociodemographic characteristics with attitude statements

\begin{tabular}{|c|c|c|c|c|c|c|c|c|}
\hline \multirow[t]{2}{*}{ Statement } & \multirow[t]{2}{*}{ Agree } & \multirow[t]{2}{*}{ Disagree } & \multirow[t]{2}{*}{ Unsure } & \multicolumn{5}{|c|}{ p-Value (chi-square / Fisher Exact test) } \\
\hline & & & & Age & Gender & Race & Education & Income \\
\hline $\begin{array}{l}\text { When I catch a cold, I will take antibiotic } \\
\text { to help to get better more } \\
\text { quickly. }\end{array}$ & $78(28.9 \%)$ & $155(57.4 \%)$ & $37(13.7 \%)$ & 0.691 & 0.824 & $0.018^{*}$ & 0.055 & $0.000^{*}$ \\
\hline $\begin{array}{l}\text { I expect antibiotic to be prescribed by } \\
\text { my doctor if I suffer from } \\
\text { common cold symptoms. }\end{array}$ & $\begin{array}{c}121 \\
(44.8 \%)\end{array}$ & $94(34.8 \%)$ & $55(20.4 \%)$ & 0.687 & 0.121 & 0.638 & $0.004 *$ & $0.011 *$ \\
\hline $\begin{array}{l}\text { I stop taking antibiotic when I start } \\
\text { feeling better }\end{array}$ & $96(35.6 \%)$ & $150(55.6 \%)$ & $24(8.9 \%)$ & 0.846 & 0.455 & 0.718 & 0.182 & $0.009 *$ \\
\hline $\begin{array}{l}\text { If my family member is sick, I usually } \\
\text { will give my antibiotic to them }\end{array}$ & $29(10.7 \%)$ & $216(80.0 \%)$ & $25(9.3 \%)$ & $0.004 *$ & 0.490 & 0.102 & $0.034 *$ & $0.00 *$ \\
\hline $\begin{array}{l}\text { I normally keep antibiotic stock at home } \\
\text { in case of emergency. }\end{array}$ & $42(15.6 \%)$ & $210(77.8 \%)$ & $18(6.7 \%)$ & $0.001 *$ & 0.503 & 0.083 & 0.575 & 0.178 \\
\hline $\begin{array}{l}\text { I will use leftover antibiotic for a } \\
\text { respiratory illness. }\end{array}$ & $17(6.3 \%)$ & $218(80.7 \%)$ & $35(13.0 \%)$ & 0.154 & 0.224 & 0.539 & 0.266 & $0.001 *$ \\
\hline $\begin{array}{l}\text { I will take antibiotic according to the } \\
\text { instruction on the label. }\end{array}$ & $\begin{array}{c}238 \\
(88.1 \%)\end{array}$ & $17(6.3 \%)$ & $15(5.6 \%)$ & 0.213 & 0.208 & 0.108 & $0.002 *$ & 0.395 \\
\hline $\begin{array}{l}\text { I normally will look at the expiry date of } \\
\text { antibiotic before taking it. }\end{array}$ & $\begin{array}{c}247 \\
(91.5 \%)\end{array}$ & $11(4.1 \%)$ & $12(4.4 \%)$ & 0.951 & 0.471 & $0.011 *$ & 0.700 & 0.481 \\
\hline
\end{tabular}

* $<<0,05$ considered as statistically significant by Fisher Exact test. Positive attitudes/responses - "disagree" for statements 1 6 and "agree" for statements 7 and 8 . Mean scores of attitude statements compared with the sociodemographic factors such as age, gender, race, education, and income.

cost of medication and diagnostic services. ${ }^{24}$ Based on this survey, a patient with good educational background tends to have poor knowledge of AMR, even though he has the knowledge to identify antibiotics and a positive attitude towards antibiotic usage. This indicates that awareness about antibiotics is important to overcome the AMR-related issues, adverse effects, and their misuse.

\section{Limitation of the study}

The data is not generalised to the whole country or other hospital settings as the study was conducted in a private set-up in only one hospital. The study method used was the convenient sampling method. Moreover, the results obtained show only a few demographic variables as the predisposing factors that correlate with the knowledge and attitude. Further multi-centric studies are required to ascertain the knowledge and attitude of patients against antimicrobial resistance.

\section{CONCLUSION}

The study concludes that the cognizance of antibiotics and antibiotics resistance are inadequate among the outpatients in a private hospital in Malaysia. Poor knowledge on antimicrobial resistance (AMR) plays a pivotal role in the inadequate awareness. This research reveals the need to implementAMR-sensitive understanding on patients upon receiving treatments by the physicians and pharmacists. It is highly important to reinforce the patient's cognizance and intensively impart AMR facts to overcome the global issues on drug-resistant and multi-drug resistant diseases.

\section{CONFLICTS OF INTEREST}

The authors declare no conflicts of interest.

\section{ACKNOWLEDGEMENTS}

The authors would like to thank KPJSSH for providing the facility for conducting the study.

\section{REFERENCES}

1. World Health Organization. Global Report on Antimicrobial Resistance. Bull World Health Organ. 2014;61(3):383-94.

2. World Health Organization. New report calls for urgent action to avert antimicrobial resistance crisis [Internet]. Joint News Release. 2019. Available from: https://www.who.int/ news-room/detail/29-04-2019-new-report-callsfor-urgent-action-to-avert-antimicrobialresistance-crisis

3. Ateshim Y, Bereket B, Major F, Emun Y, Woldai B, Pasha I, et al. Prevalence of selfmedication with antibiotics and associated factors in the community of Asmara, Eritrea: A descriptive cross-sectional survey. BMC Public 
Health. 2019;19(1):1-7.

4. Barker AK, Brown K, Ahsan M, Sengupta S, Safdar N. Social determinants of antibiotic misuse: a qualitative study of community members in Haryana, India. BMC Public Health. 2017 Dec 19;17(1):333.

5. Uchil RR, Kohli GS, Katekhaye VM, Swami OC. Strategies to combat antimicrobial resistance. J Clin Diagnostic Res. 2014;8(7):811.

6. Ahmad N. National Antibiotic Resistance Surveillance Report 2017 [Internet]. Institute for Medical Research, Ministry of Health Malaysia. 2017. p. 1-34. Available from: https://www.imr.gov.my/en/component/ content/article/75-english-content/nationalcollabration/1469-nsar-main.html

7. Islahudin F, Tamezi AMA, Mohamed Shah N. Knowledge, attitudes and practices about antibiotic use among the general public in Malaysia. Southeast Asian J Trop Med Public Health. 2014;45(6):1474-82.

8. Lim KK, Teh CC. A Cross-Sectional Study of Public Knowledge and Attitude towards Antibiotics in Putrajaya, Malaysia. South Med Rev. 2012 Dec;5(2):26-33.

9. Leong TW, Rahmah S, Ishak S, Ali Z. Knowledge, attitude and practice of antibiotics prescribing among medical officers of public health care facilities in the state of Kedah, Malaysia. Med J Malaysia. 2015; 70(5):307-11.

10. Sadiq MB, Syed-Hussain SS, Ramanoon SZ, Saharee AA, Ahmad NI, Mohd Zin N, et al. Knowledge, attitude and perception regarding antimicrobial resistance and usage among ruminant farmers in Selangor, Malaysia. Prev Vet Med. 2018 Aug;156:76-83.

11. Dyar O, Hills H, Seitz L-T, Perry A, AshiruOredope D. Assessing the Knowledge, Attitudes and Behaviors of Human and Animal Health Students towards Antibiotic Use and Resistance: A Pilot Cross-Sectional Study in the UK. Antibiotics. 2018 Jan 30;7(1):10.

12. Ling Oh A, Hassali MA, Al-Haddad MS, Syed Sulaiman SA, Shafie AA, Awaisu A. Public knowledge and attitudes towards antibiotic usage: a cross-sectional study among the general public in the state of Penang, Malaysia. J Infect Dev Ctries. 2010 Nov 9;5(05):338-47.

13. Daniel WW. Biostatistics: A Foundation for Analysis in the Health Sciences. Biometrics. 1995 Mar;51(1):386.

14. Voidăzan S, Moldovan G, Voidăzan L, Zazgyva A, Moldovan H. Knowledge, Attitudes And Practices Regarding The Use Of Antibiotics. Study On The General Population Of Mureş County, Romania. Infect Drug Resist. 2019 Oct 31, 12:3385-96.

15. Sutthiruk N, Considine J, Hutchinson A, Driscoll A, Malathum K, Botti M. A survey of reported behaviours, attitudes and knowledge related to antibiotic use of hospitalised patients in Thailand. Infect Dis Heal. 2018;23(4):20310.

16. Ekambi GAE, Ebongue CO, Penda C, Nga EN, Mpondo EM, Moukokoid CEE. Knowledge, practices and attitudes on antibiotics use in Cameroon: Self-medication and prescription survey among children, adolescents and adults in private pharmacies. PLoS One. 2019;14(2):1-17.

17. Wang W, Wang X, Hu YJ, Wu D, Lu J, Xu Y, et al. The Misconception of Antibiotic Equal to an Anti-Inflammatory Drug Promoting Antibiotic Misuse among Chinese University Students. Int J Environ Res Public Health. 2019 Jan 25;16(3):335.

18. Haenssgen MJ, Charoenboon N, Zanello G, Mayxay M, Reed-Tsochas F, Lubell Y, et al. Antibiotic knowledge, attitudes and practices: new insights from cross-sectional rural health behaviour surveys in low-income and middleincome South-East Asia. BMJ Open. 2019 Aug 20;9(8):e028224.

19. You JHS, Yau B, Choi KC, Chau CTS, Huang QR, Lee SS. Public Knowledge, Attitudes and Behavior on Antibiotic Use: A Telephone Survey in Hong Kong. Infection. 2008 Apr 29;36(2):153-7.

20. Shehadeh M, Suaifan G, Darwish RM, Wazaify M, Zaru L, Alja'fari S. Knowledge, attitudes and behavior regarding antibiotics use and misuse among adults in the community of Jordan. A pilot study. Saudi Pharm J. 2012 Apr;20(2):12533.

IMJM Volume 20 No.3, July 2021 
21. Yusef D, Babaa AI, Bashaireh AZ, Al-Bawayeh HH, Al-Rijjal K, Nedal M, et al. Knowledge, practices \&amp; attitude toward antibiotics use and bacterial resistance in Jordan: A crosssectional study. Infect Dis Heal. 2018 Mar;23 (1):33-40.

22. Che Roos N, Bakar M, Haque M. Knowledge, attitude and practice among Malaysian medical students, doctors, other health professionals and common people regarding antibiotic use, prescribing and resistance: A systematic review. Adv Hum Biol. 2019;9(3):179.

23. Kong LS, Islahudin F, Muthupalaniappen L, Chong WW. Knowledge and Expectations on Antibiotic Use among Older Adults in Malaysia: A Cross-Sectional Survey. Geriatrics. 2019 Oct 25;4(4):61.

24. Nepal A, Hendrie D, Robinson S, Selvey LA. Knowledge, attitudes and practices relating to antibiotic use among community members of the Rupandehi District in Nepal. BMC Public Health. 2019;19(1):1-12.

25. Qamar M, Abdullah NHS, Khan J, Mahmud A, Ahmad A. Knowledge and Attitude towards Antibiotic Usage among General Public in Shah Alam, Malaysia. UK J Pharm Biosci. 2014;2 (6):60. 